\title{
STRATEGIC MANAGEMENT OF ENTERPRISE ECONOMIC SECURITY
}

\section{Zhuk V.P.}

\section{INTRODUCTION}

Every system, as well as anybody in general needs security. Enterprises are also drawn to security. Security is one of the most important conditions of the enterprise functioning. Among the numerous researches of security the research of enterprise economic security is the most popular today. However, inspite of the actuality and popularity of such researches, the form and the content of the enterprise economic security management are in the inconsistent state, and the conceptual principles of such management can not be acknowledged as harmoniously put together. Concurring with the classics' opinion concerning the necessity of keeping to the unity of form and content in science, it should be noted that the achievement of the goals of enterprise economic security management is only possible at the terms of creation of clear and logical concept of such management. In the context of constant environmental threats modern business entities are increasingly facing problems of ensuring the effectiveness of their activities, which is caused by the fact that emerging phenomena and trends of the development in the environment do not always have a positive impact on the operation of economic entities. Some changes in the environment result in dangers and threats to an enterprise and, sometimes, act as catalysts for deterioration of its condition. That is why the necessity to protect enterprise activity as well as its position on competitive markets, which consequently ensures the economic security of business entities, is a logical response to negative changes in the environment.

\section{Economic security: the main principles and components}

Economic security of an enterprise is characterized by its economic status that ensures sustainability of its operations and development, its financial and commercial success. The problems of security arrangements, being recently the matter of importance, are presented in the world 
scientific literature from the perspective of risk coverage and assessment of its consequences. In practice there are certain ways of enterprise economic security development and in most cases they are strategically directed, accompanying the processes of qualitative organizational, innovative and investment changes and creating conditions for enterprise's stable and effective activities.

The economic success of firms is largely determined by the provision of economic security. Enterprise economic security is the state of security of the enterprises from the adverse impact of internal and external threats, destructive causes, which allow sustainable implementation of the main commercial interests and the purposes of the statutory activity. Economic security is ensured by implementation of measures of economic security, whose main aim is to maximize safety and minimize potential damage. Here are the main tasks for ensuring economic security: interests;

- Legal protection of trade secrets of the organization and its

- The acquisition of necessary information by conducting marketing research;

- Detection of external and internal threats, the suppression of economic intelligence by competitors, unauthorized or criminal activities by employees;

- Security organizations and objects located on it;

- Compensation for material and moral damages if it was caused by illegal influences businesses and individuals;

- Controlling the activities of the security system, improvement of its elements.

In general, the system of economic security of enterprise is individual, during its formation must consider not only the above problems, but the scope of activities, the conditions of competitiveness. How and in what scale is realized by the system is determined by the normative-legal base of the state, budget of the firm, knowledge and leadership experience in the field of economic security. The establishment of a durable system of economic security of an organization cannot be achieved without its compliance with this series of principles:

1. Comprehensiveness - the system must ensure the safety of various areas of activity of the enterprise. 
2. The priority of preventive measures (warning) is a system security required at the initial stages to detect various negative factors.

3. Consistency - security system may be continuous under the condition of failure-free operation of its elements.

4. The legality - all actions to ensure security of the enterprise should be based on the existing regulations and not to contradict him.

5. Planning - logically sequential execution of actions in the system, making the system organized.

6. Low cost - the cost of the system must not exceed the income from the activities of the enterprise.

7. Interaction - all elements of the system are functioning in a coordinated way; the function of each element is clearly defined.

8. Competence - ensuring economic security should be entrusted to professionals with the necessary level of training, knowledge in this area.

Thus, economic security is one of the main components of enterprise management, working for its success. To build a reliable system of economic safety of the enterprise requires specific competence in this field, setting clear goals, objectives and compliance with the basic principles.

Today, the problem of determining the essence of economic security of an enterprise is characterized by a great number of scientific ideas. Economic security of an enterprise was considered just as a practical task some time ago; so taking this fact into account we should admit the lack of a unified approach of researchers to the essence of the concept "enterprise economic security". The purpose and objectives of the study. Considering the above, the purpose of the study is to systematize approaches to the interpretation of the concept of "economic security of an enterprise".

The economic security of an enterprise is a synthetic category of political economy and political science, which are closely linked to the categories of economic independence and dependence, stability and vulnerability, economic sovereignty and economic pressure, blackmail, coercion and aggression.

The term "economic security" was firstly used during the Great Depression in the United States. At that time, the idea of economic security was associated with individuals, and actions ensuring it were directed at harmonizing the social situation in the country and at developing public retirement income system and social insurance of the unemployed. In 
Ukraine, economic security was firstly mentioned during the period of independence. But today there are many definitions of the concept "enterprise economic security" and a wide variety of ideas as for the essence of this category.

Some scientists said that the economic security of an enterprise is a complex characteristic, which means the level of protection of all types of enterprise's potential against internal and external threats, which ensures stable operation and effective development, and also requires business administration management. One of them proves that the economic security of an enterprise is a set of factors that provide independence, stability, ability to progress under destabilizing factors. L. Yurovich considers the company's economic security as the protection of the enterprise against negative impacts of external and internal environment, the ability to eliminate various threats quickly or adapt to external conditions without negative consequences for the enterprise. According to M. Bendikov, the economic security of the enterprise represents the protection of its scientific, technological, production and personnel potential against direct and indirect threats. ${ }^{1}$

O. Illyashenko states that a large variety of definitions of the concept of "economic security of an enterprise" is associated with the number of its attributes.

There are some definitions of "enterprise economic security":

1. Competitive advantages caused by the correspondence of the material, financial, personnel, technical and technological potential and the organizational structure of an enterprise to its strategic goals and objectives.

2. Business conditions under which the entity, using the corporate resources in the most efficient way, prevents or eliminates the influence of existing threats or other unforeseen circumstances or protects itself against them, and in general ensures achieving the main business objectives in the conditions of competition and economic risk.

3. Protectability of a business entity from the negative effects of external environment, as well as the ability to eliminate quickly various threats or adapt to existing conditions that do not affect its activities negatively.

\footnotetext{
${ }^{1}$ Stratan, I. (2007). Bezopasnost' biznesa [Business security]. ELAN-POLIGRAF, 124 p.
} 
4. Harmonizing in time and space economic interests of an enterprise with the interests of external environment involved and their partial protection against threats.

5. The process aimed at protecting the entrepreneurial structures and individuals whose activities include elements of entrepreneurship against criminal competitiveness and other methods that harm them due to violations of law and business ethics.

6. The most effective use of corporate resources in order to prevent threats and to ensure the sustainable operation of an enterprise at present and in future.

7. The most efficient use of resources in order to eliminate the threats and ensure the effective and stable operation of an enterprise at present and in future.

It should be noted that the following definitions of "enterprise economic security" can be attributed to several approaches, which characterizes the phenomenon of economic security as a complex interdisciplinary category and represents its intrinsic qualities. The economic security of an enterprise is a state of the entity as an economic system in which it is capable to respond adequately and prevent effectively all existing threats, both internal and external.

Economic security of an enterprise is defined as a complex category that characterizes the ability of the systems created at the enterprise to withstand the destabilizing effects of internal and external factors in order to ensure the efficient use of its resources (capital, personnel, technology, information, technology, etc.), existing market opportunities (competitiveness), as well as fulfillment of other statutory tasks in the current period and in the future. There is also a concept such as "integrated system for providing enterprise economic security", which includes a certain set of interrelated elements (measures of organizational, economic and legal nature) that, when the enterprise reaches the main objectives of the business, provides its security against real or potential threats that can lead to material losses. The essence of the company's economic security is to ensure its progressive economic development in order to produce the necessary goods and provide services that meet the needs of the enterprise and social needs. Economic security of the enterprise manifests itself in ensuring its stable activity, preventing the leakage from it of any information. The material basis of economic security of an enterprise is its 
economic potential, which determines the possibility of protecting the economic system from the adverse effects of the internal and external environment. The analysis of numerous external hazards and threats, directions and objects of their actions, possible consequences for business is associated with long-term research. Nevertheless, each enterprise and, above all, business managers, considering particular situation their business face, should determine (predict) the most significant (dangerous) problems and develop a system of measures to detect them timely, reduce their influence, prevent them.

Economic security of the company is conditioned to the interaction of various factors. Some factors for a particular period of time can be considered definite (for example, technical characteristics of fixed assets, number of employees, etc.). Others are subject to significant changes over a relatively short period of time (eg fluctuations in product prices, supply and demand levels, level of investment activity, etc.). A number of factors can not be precisely quantified. External and internal factors can cause damage to the economy of the enterprise in four cases:

1. The system of economic security of the enterprise is constructed in such a way that it can not foresee a threat to its occurrence.

2. The threat arose, but officials responsible for the economic security of the company can not foresee it.

3. The threat is detected, but the management of the company is not able to prevent its negative consequences.

4. Enterprise management tries to solve the problem, but its actions do not lead to a positive result.

Since all factors are closely interrelated and have a comprehensive impact on the processes of economic security, enterprises need a comprehensive study of the whole set of operating factors. A detailed analysis of the conditions and factors of economic security allows the company to develop measures for the formation of mechanisms and systems of protection against dangers and threats. The more developed other systems, the less destructive forces that lower security parameters.

Modelling of factor system of enterprise economic security envisages the compliance to the processes of changes of its financial and economic status, development of essential properties and relations within the enterprise system. The process of modelling and analysis consists of the following steps: 
- the research concept is to be formed with the object of factors of changes of enterprise financial and economic status and a set of criteria and indicators which characterize these processes;

- the methods of mathematical modelling and evaluation of factors of economic security are identified;

- the results are interpreted and analyzed.

\section{Economic security: main evaluation criteria}

The basic idea of the research is that the identification of economic security factors involves the development of properties of enterprise economic strength - adaptivity, reliability, flexibility, mobility, adequacy and etc. It is necessary to consider the following:

- the main feature of economic strength is its integrity that results from the interaction of its components and determines the level of its development according to the weakest element;

- the priority of enterprise economic goals and economic results ensures the adequacy of all components within economic strength to achieve long-term development goals owing to enterprise efficient operations;

- the boundary value of adaptivity to the terms of changeable internal and external environment is determined by its stability and economic security. $^{2}$

The first and the second statements allow choosing among all the indicators of enterprise activity - those that ascertain profitability (resources usage, efficiency of business operations and economic activity). The third statement stipulates the necessity of using liquidity ratios and business solvency figures. ${ }^{2}$

Economic security evaluation is an integral management tool, as it creates an information base for making strategic management decisions to ensure a long-term performance of an enterprise. Such evaluations should be based on the cause-andeffect relations between the processes of production and economic activities for the complete consideration of all impact factors. For this purpose an economic security configuration of strategic enterprise development, which includes the following areas of evaluation: "interests", "economic and financial stability", "effective

\footnotetext{
${ }^{2}$ Kopylyuk, O. I., \& Muzychka, O. M. (2015). Formation of the system of financial and economic security of business structures, $98 \mathrm{p}$.
} 
functionality" "organizational adaptability", "strategic competence", was formed. Under the conditions of global integration and globalization the economic efficiency of modern industrial enterprise depends on establishing and maintaining close relationships with 4 types of partners: state, competitors, customers and suppliers, interest groups. Peculiarities of such relationships reflect the interests of enterprise, form various types of strategies and can be organizationally expressed in the form of state protectionism, association, affiliation, alliance, league of public providers, political and technological strategies, political and trade-union strategies etc. By implementing such strategies, an enterprise may secure itself against a variety of possible risks, creating the socalled "niche security" where it is protected from competition and which allows entering competitive struggle at exposed markets. In this sense there is a threedimensional definition of a business strategy in a certain type of activity. Among the measurements it's important to mention the following:

- value or attractiveness of business areas;

- enterprise competence in this area of activity, which manifests itself as a competitive position;

- security, defined by the importance of existing organizational relations in order to avoid competition.

Indicators for the evaluation of enterprise's and its partners' interests include:

- the exchange index of best practices among partners;

- the activity index in cooperation with universities;

- state support index;

- the activity index in cooperation with competitors;

- the activity index in cooperation with customers.

Financial analysis is the primary task of effectiveness evaluation of production and economic activity according to the indicators: absolute, quick and current liquidity, autonomy, equity and return on assets. Adaptivity is a state of organizational structure that allows responding flexibly to changes in the environment. The indicators for such evaluation are: the index of organizational experience gaining; the integration index; the index of productive diversification development; the specialization index; the index of outsourcing expenditures. The component of adaptivity of organizational structure reflects the main results obtained by means of diversification, integration and specialization. Particular attention should 
be paid to the specialization index, calculated by the method of R. Rumelt which is detalized in the scientific work of A. Nalyvaiko in the context of research of productive diversification processes and systems of its effectiveness measurement. Within the today's realities of Ukrainian machine-building, a set of indicators reflecting the effectiveness of the key functional fields of activity was formed: innovative development index, renewal product offering index, index of reduction of project design duration; index of increasing own innovative base; innovation development index. Evaluation of enterprise strategic competence is based on the usage of such indicators: index of managerial staff education; management standartization index; index of return on costs for managerial knowledge development; index of managerial knowledge formalisation; index of bench-marketing costs.

\section{System of economic security of the enterprise (SEES)}

In modern conditions, economic activity of economic entities is influenced by macroeconomic factors (state of law legislation, political and socio-economic situation in the country), and microeconomic (personnel, capital adequacy, management system), which exacerbates the problems of managing economic security enterprises. Among the problems of managing the economic security of enterprises to be resolved, first of all, the following should be mentioned:

- incomplete certainty with a set of components of the economic security of the enterprise;

- the existence of significant difficulties in the formal description of the dynamic properties of the enterprise in order to ensure its economic security in connection with the actions of destabilizing factors;

- existing difficulties in determining the composition of the assessment criteria of the components of economic security, as well as their gradation for different levels of security;

- there are no generally accepted domestic methods for assessing the level of the components of economic security of an enterprise, since approaches that have been recognized in foreign practice cannot always be applied in the conditions of a transitory economy of Ukraine;

- lack of a methodology for the complex assessment of the level of economic security of an enterprise, taking into account all its components. This problem is quite significant, since the levels of different components 
are determined on different scales, which complicates their erection into a single complex indicator.

There are many factors that can negatively affect the ability of an enterprise to successfully carry out its activities. According to the State Statistics Committee of Ukraine: out of 100 enterprises registered as business entities, only about 15 continue their activities, others in the period up to five years are eliminated. According to the data presented in figure. Since 2010, the losses of Ukrainian enterprises have started to grow significantly. This situation was caused by the global financial crisis. Thus, in 2011, the total number of enterprises that are in bankruptcy proceedings has increased by $38 \%$ more than in the previous year, while the share of loss-making enterprises was $6.2 \%$. In January-September 2013, 42.6\% of domestic enterprises worked at a loss. According to statistics, in 2014, the ratio of profitable and loss-making enterprises was $58.6 \%$ and $41.4 \%$. The number of unprofitable industrial enterprises of Ukraine in 2015 increased from $41.4 \%$ to $42.2 \%$ in comparison with the corresponding period of last year. Keeping such trends in the future will lead to the bankruptcy of many enterprises.

Therefore, an effective SEES involves developing certain, mutually agreed with the strategy of enterprise policy that is reasonable guidelines, which contributes to achieving the necessary level of security. To justify these guidelines, it is necessary to determine the totality of the goals of the organization. The achievement of certain goals is possible through the use of a certain set of tools (technical, organizational, informational, financial, legal and personnel) through the implementation of clearly directed actions. Economic security of an enterprise is a state that provides the most efficient use of enterprise resources to ensure stable operation and development, in which it is able to maximize its value at an acceptable level of risk. The objective of managing the company's economic security is to effectively protect the vital economic interests of a particular security object from threats of external and internal character. The most important goals of economic security of the company include the provision of operational efficiency, financial stability and independence of the enterprise. In scientific practice, the main tasks to be addressed by an enterprise's economic security management system are: the development of tools and effective mechanisms for reducing the impact of threats and supporting sustainable development of the enterprise; forecasting and 
monitoring of possible critical threats to the enterprise's economic security; improvement of the mechanism of ensuring economic security; assessment of risks and threats using modern quantitative and qualitative methods. ${ }^{3}$ The objects of the SEES include:

- the direction of the main activities of the entity (supply, management, commercial, industrial);

- property and resources owned by the enterprise (material, technical, financial, intellectual, information);

- personnel, structural divisions, services.

The main subjects of the SEES are officials, services and units involved in security provision. Given the complexity and complexity of the content of this category, it should be considered as an interconnected system. Under the system of economic security of the enterprise (SEES) is understood the organized set of special bodies, services, means, methods and measures that provide protection of vital interests of the enterprise from internal and external threats. The main components of ${ }^{3}$ economic security are: the object and subject of economic security, the purpose of economic security, the task of economic security and the mechanism for ensuring economic security. Consistent refinement of the content and nature of categories and concepts that are part SEES (table) to determine that danger - is causing damage to the company, which is close to the possibility of implementation; risks - high probability of occurrence of losses, deviation from the planned; threats - arise on the basis of the contradictions that are economic relations regarding the realization of the economic interests of the subjects; challenges - circumstances that shape future threats and opportunities depending on the timeliness of the reaction and the formation of the correct answer preparation.

The basis for raising the level of economic security of economic entities is the formation and development of a modern SEES, the specific principles of which are complexity, adaptability, flexibility, stability, efficiency, reliability and selforganization. The system of measures should be aimed at achieving (maintaining) an appropriate level of economic security: ensuring optimal combination of resources and available opportunities of the enterprise, detection and neutralization of threats, compensation of damages and reproduction of protected objects in case of

\footnotetext{
${ }^{3}$ Volkova T.A., Volkova S.A. Mechanism of providing economic safety of the enterprise. Topical issues of development of modern society. Collection of scientific articles of the VI International scientific and practical conference, $2016.24 \mathrm{p}$.
} 
realization of hazards. The effectiveness of the SEES is determined by the main indicators of its activities: the stability of functioning; proper level of competitiveness; increase in the wealth of owners (shareholders); Sustainable innovation development of the enterprise; harmonization of socioeconomic interests.

In order to have a comprehensive assessment of the SEES, it is necessary to use a modern system of indicators. Indicators of economic security are indicators that characterize the state of the factors of economic security of the enterprise. Indicators include a system of indicators: the macro level that characterizes the state of the environment (changes in legislation, the level of macroeconomic instability), mesoroveness (regional policy, resource security of the territory) and the micro level (labor supply, the quality of working life). Political, ecological, economic, social, techno-technological and legal factors were identified as the main tendencies of the impact on the operation of the company at the macro level. Mileage of the system of economic security can be investigated both in branch and in the territorial aspect. In the sectoral aspect, as a factor contributing to the threat, the characteristics of the sphere of the functioning of the business structure are considered. The mist from the position of the territory assumes the characterization of a particular region as a threat.

In order to assess the economic security of the enterprise at the micro level, all indicators can be divided into categories: financial indicators; production and sales; indicators of innovation activity; social indicators. An integral assessment of economic security taking into account risks and threats at all levels will identify those security objects that require the development of a mechanism and instruments for increasing economic security.

Eurointegration conditions oblige to implement effective management of economic safety of the enterprise. That is why it is important to create the following subsystems of economic security in order to reduce the threats to enterprises and also to effectively manage economic security:

- analytical subsystem, that is, having at its disposal specialists, tools and methods for diagnosing the internal and external environment of the organization;

- subsystem of planning and forecasting, which allows to determine the goals and objects of management of the organization; 
- an effective executive subsystem (for carrying out control activities), which allows to quickly and accurately implement a managerial influence;

- information subsystem, which includes financial and managerial accounting. Allows you to at any time provide management of up-to-date, complete and accurate information about the state of the managed object and the environment, as well as trends in their future changes;

- subsystem feedback (making managerial decisions in the middle of the organization) to assess the result of the control effect on the state of the object of management and making corrections in the event of a deviation of the achieved state of the system from its desired state beyond the range of acceptable deviations.

On the basis of the expert research (2016) of industrial enterprises and service enterprises, the following risks and threats from European integration were identified. For the investigated companies, the main threat is military actions, political instability in the country, increased competition in the domestic market, costs for the transition to international standards, loss of markets in the Russian Federation. Features of industrial enterprises include: the need for modernization of equipment, increased costs for compliance with environmental policy, a large number of documents, costs and time for export, additional costs for compliance with safety.

The priorities of the enterprises for European integration are defined, namely: harmonization of domestic and international standards of production and quality of products, access to the EU market, lower prices for equipment for modernization, reduction of customs tariffs and duty-free quotas, the possibility of expanded cooperation with foreign partners. Since the conditions of the European integration process of Ukraine took place at the interstate level, the same state has a significant influence and can give a significant impetus to enterprises in their development in this direction. Therefore, the process of managing the economic security of enterprises in the context of European integration should involve the involvement of both the owners (through the construction of the appropriate mechanism) and the state, since its role today is largely determinative for business. 


\section{CONCLUSIONS}

Scientific novelty of the conducted research is in improving the complex assessment of the SEES, which includes indicators of the macro-, meso-, macrolevels of the enterprise. The theoretical significance of the research results is revealed in the identification of the elements of the SEES and the disclosure of their content characteristics. The practical value of the research results is to isolate strategic threats and priorities in the management of the SEES. The strategic orientation of business in the process of European integration should be aimed at studying and taking into account: EU legislation on export-import issues, market trends of EU countries, European standards and requirements for the production and sales of products, increasing the competitiveness of products.

The direction of further research on the management of the economic safety of the enterprise is the development of a methodical tool for assessing the level of economic security of an enterprise in the context of European integration. Research results can be used for companies with European orientation.

\section{SUMMARY}

The management system directly depends on the information scope, quality, and intended use. Traditional methods and tools of information preparation do not adequately meet the requirements of modern management, and hence qualitatively and quantitatively new scope of information is required, as well as their structuring considering the influence of risks and uncertainties of the market environment. Creation of the through-flow system of accounting and analytical support as a key component to ensure financial stability and economic security has to be the key to long-term effective strategic development and management of the company.

The effectiveness of the company's strategic management is a complex task mainly dependent on consistency and perfect functioning of the mechanism of collection, accumulation, processing, storage, analysis, and transfer of information and the subsequent mechanism of management decision approval. Currently, many scientific approaches to building the accounting and analytical system are developed and there are many developments related to its component structure, principles, and relationships. However, the main drawback of the existing approaches to 
forming the system of accounting and analytical support is that mostly the system outline, components, specific methods, and approaches to accounting and analysis are determined, but the system is not seen as a whole dynamic tool to provide a focused development tool (transfer of the enterprise as a control object from one state to another) in a certain time period. Therefore, one of the priorities in development of the enterprise's accounting and analytical system is its construction under the principles and approaches of logistics management, allowing to form the necessary data information array in a single space, providing a unified approach to information preparation and, at the same time, to avoid information isolation of individual management units, duplication and "overproduction," and data misrepresentation. In addition, each system requires formation of feedback provided to some extent by management control functions. In this regard, accounting and analytical support for economic security was proposed to be used as a system to provide assessment and control of the enterprise's strategic development.

Due to economic security tools, retrospective, current, and preventive control of decisions should be achieved. Issues on detailed development of indicators and criteria of economic security require for further fundamental studies for the purpose of effective analysis and control.

\section{REFERENCES}

1. Ansoff, I. Strategies for Diversification. Harvard Business Review, $35(5)$.

2. Bogomolov, V. A. (2011). Economic security : teaching. Manual. Moscow : UNITIDANA.

3. Cherevko, O. V. (2019). Stratehichne upravlinnya finansovoekonomichnoyu bezpekoyu pidpryyemstva [Strategic management of financial and economic security of an enterprise].

4. Dotsenko, I. O., \& Melnychuk, O. P. (2018). Stratehichne upravlinnya finansovo-ekonomichnoyu bezpekoyu pidpryyemstva [Strategic management of financial and economic security of the enterprise].

5. Endovitskaya, A. V., Volkova, T. A., \& Baliashvili, D. U. (2014). Theoretical and methodical approaches to the definition of the essence of economic security of the enterprise and its evaluation. Modern economy: problems and solutions. 
6. Goncharenko, L. P. \& Kucenko, E. S. (2009). Upravlenie bezopasnost'ju [Security management]. KNORUS.

7. Kopylyuk, O. I., \& Muzychka, O. M. (2015). Formation of the system of financial and economic security of business structures.

8. Lasan, N. (2010). Security: concepts in contemporary society. Revista de Administrație Publică și Politici Sociale, An II, Nr. 4(5).

9. Stratan, I. (2007). Bezopasnost' biznesa [Business security]. ELAN-POLIGRAF.

10. Volkova, T. A., \& Volkova, S. A. (2016). Mechanism of providing economic safety of the enterprise. Topical issues of development of modern society. Collection of scientific articles of the VI International scientific and practical conference.

11. Wysokińska-Senkus, A., \& Raczkowski, K. (2013). Economic security in the context of sustainability. Aleksandras Stulginskis Univ., 6(1).

12.Zachosova, N. V. (ed.). (2016). Formuvannya systemy ekonomichnoyi bezpeky finansovykh ustanov [Formation of the system of economic security of financial institutions].

\section{Information about the author: Zhuk V.P.}

Candidate of Public Administration, Associate Professor of Department of Economics, Entrepreneurship and Natural Sciences, V. I. Vernadsky Taurida National University 33, John McCain str., Kyiv, 02000, Ukraine 